Kovács Béla

\title{
Ezüst szárnyak - A Magyar Királyi Honvéd Légierő ezüst festésű FIAT CR-32-es vadászrepülőgépei
}

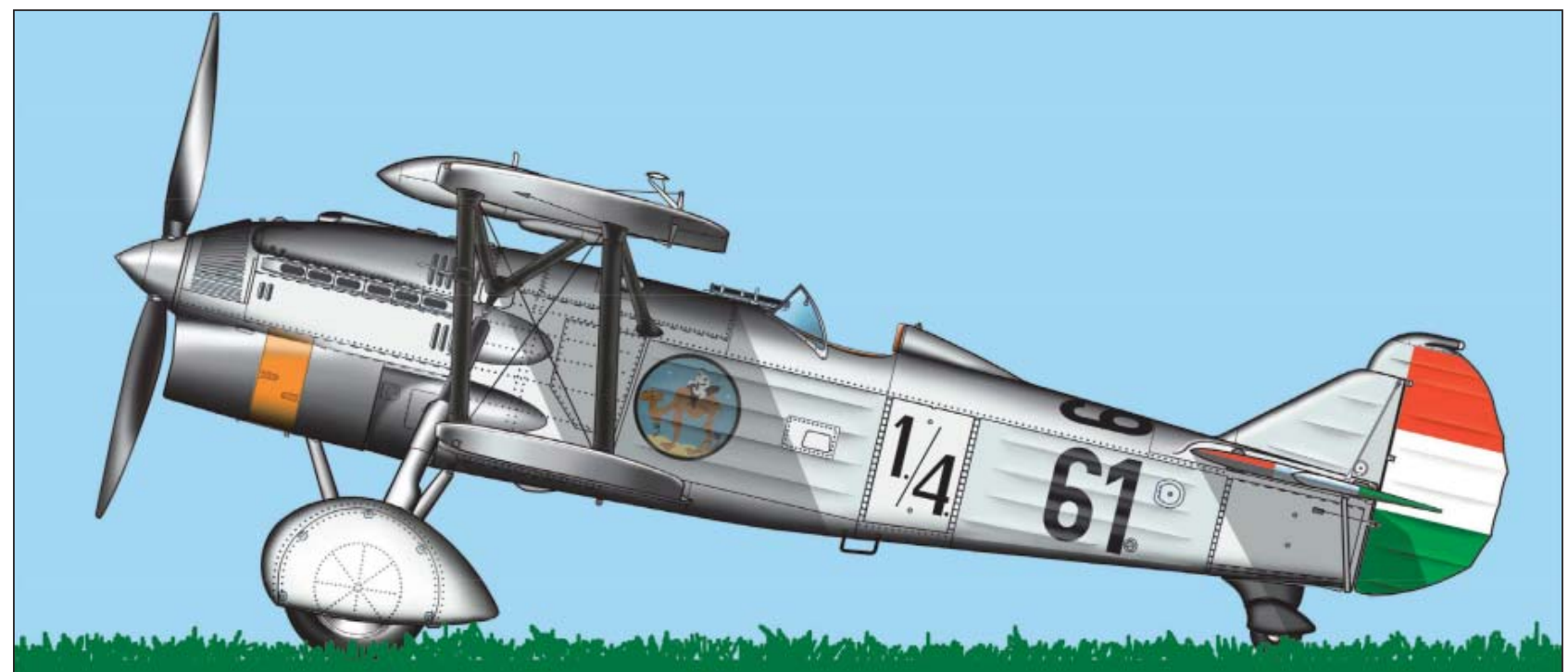

1. ábra. Az 1/4-es Teve század 61-es kötelékszámú gépe 1937-38-ban. A Teve század 1936-1940 között repült 32-eseken, utána átfegyverezték 42-esekre, egyúttal századjelvényt is váltottak. A 42-esekre Mátyásföldön a Szent György jelvényt festették fel

A CR-32-eseket a gyártó egységes ezüst festéssel szállította. Az alumínium pigmentet tartalmazó festék az alulemez borítású felületeknek pótlólagos korrózióvédelmet biztosított, a repvászonnal borított részeket pedig védte a Nap UV sugárzásától. A vászonfelületeket előzőleg gombaölővel kezelték és több réteg vászonfeszítő lakkal biztosították feszes felfekvését. A vásznat hozzávarrták a bordákhoz és hosszmerevítőkhöz. Az ezüst festék biztos tapadásához is alapozófestéket használtak. A vászon felületeket egyébként ecsettel ajánlják festeni, segítségével a festéket belenyomkodják a szövet fonásába. Fontos a felületek érdességének csökkentése. Az érdes felület akár $20-30$ km/h-val is csökkentheti a sebességet és például a CR-32-es $375 \mathrm{~km} / \mathrm{h}$ csúcssebességéhez képest ez az érték már túl sok. A felületeket csiszolják és polírozzák, a felvitel utáni 4-5 mikronos felületei érdességet 1 mikronra csökkentik. A háború elején kiadott német festési utasításban azonban határozottan megtiltják a felületek tisztítását és még a kipufogócsöveket is terepszínüre festetik. A hozzánk került CR-32-esek változatos módon kerültek a rejtett légierő birtokába. Például az 1936. június 11-i, úrnapi mátyásföldi repülőnapra érkezett az északolasz Goriziaból a 4. Stormo 10. Gruppo 91. Squadrigliaja, Viola százados vezetésével (aki később Spanyolországban
ÖSSZEFOGLALÁS: A FIAT CR-32-es vadászrepülőgépek Olaszországból ezüst védőfestéssel kerültek a titkos, vagy más néven rejtett légierőnkhöz, mivel a gyártó egységes ezüst festéssel szállította ezt a típust. A hozzánk került CR-32-esek változatos módon kerültek a rejtett légierő birtokába. Például az 1936-os mátyásföldi repülőnapra érkezett 11 db CR-32 vadászgép a bemutató után „valahogy” itt maradt. A Puma vadász-század a későbbiekben használt osztrák eredetü CR-32-eseket is. Az osztrákok 36 gépet adtak át Magyarországnak. A csehszlovák válság idején a CR-32-esek már egyszínü zöld terepszínben kerültek alkalmazásra.

KULCSSZAVAK: Magyar Királyi Honvéd Légierő, FIAT CR-32 vadászrepülőgép, ezüst festés
ABSTRACT: From Italy, the secret or covered Royal Hungarian Air Forces got the FIAT CR-32 fighters with silver protective paint coat, since the manufacturer delivered the planes of this type with this standard silver painting. There were several ways the covered air force received these aircraft. For example, the eleven CR-32 fighters came for the Air Show at Mátyásföld in 1936 remained behind 'somehow'. Later on, the Puma fighter squadron used originally Austrian CR-32s, too. The Austrian handed over 36 aircraft. The CR-32s put into action in the course of the Czechoslovakian conflict, had already standard green camouflage painting. 


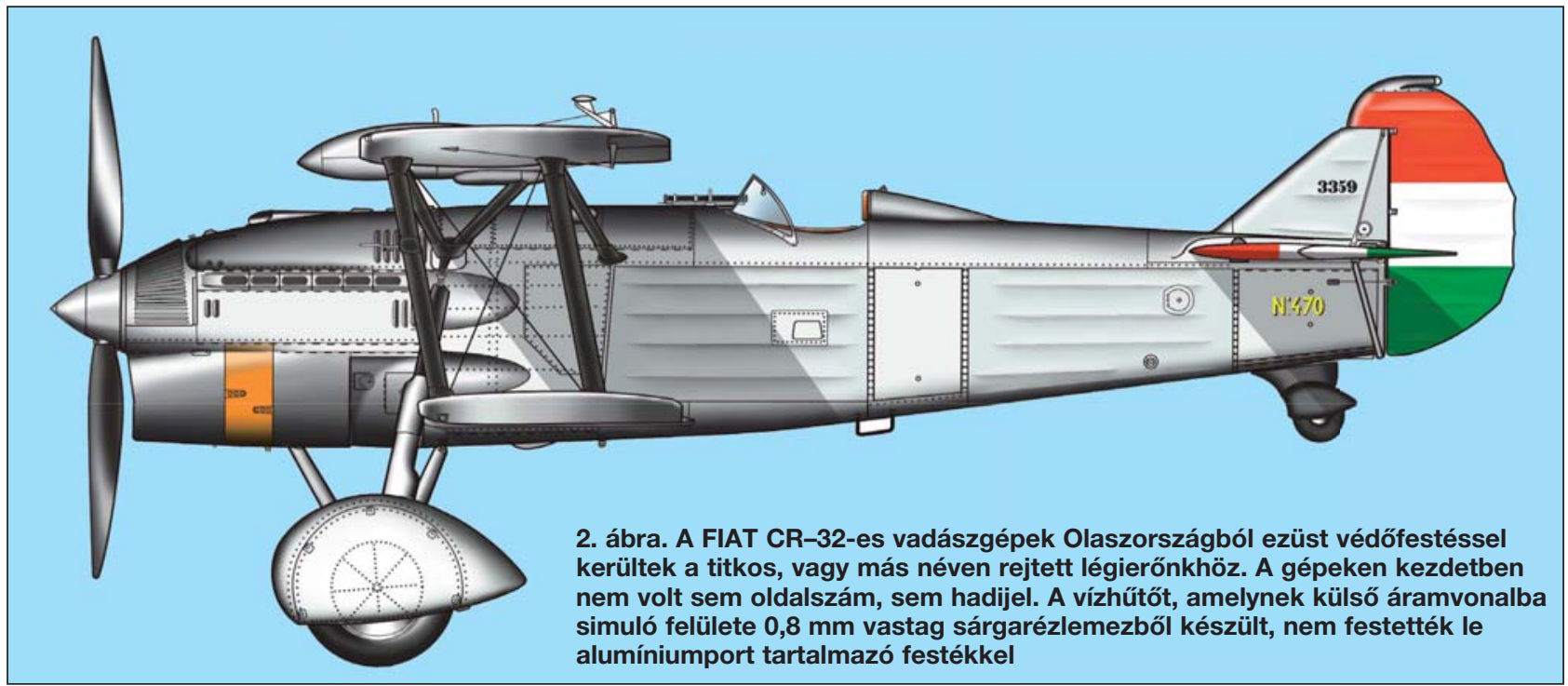

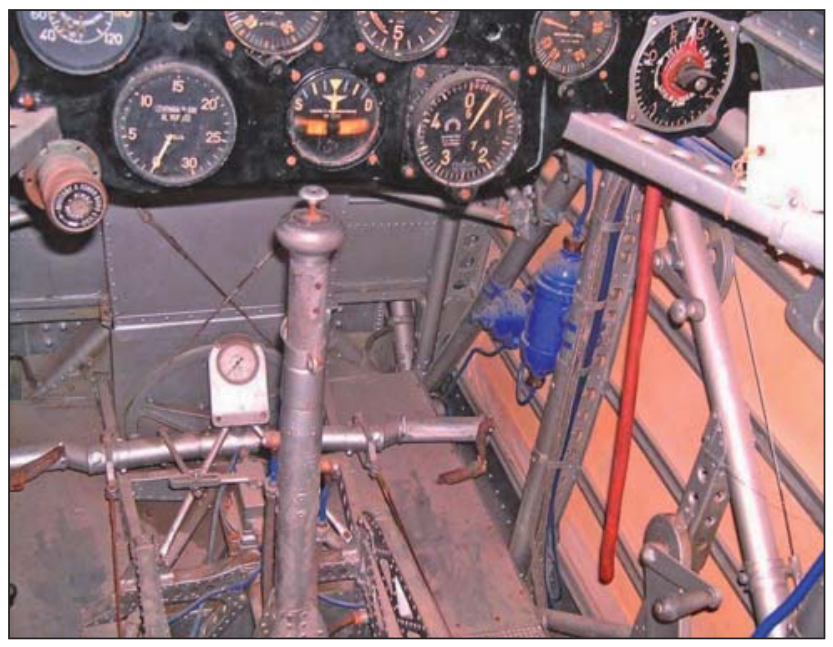

3. ábra. Múzeumi CR-32-es vadászgép kabinja. A jobb oldalon, a törzsoldal vásznazásán átüt a vörös vászonfeszító lakk harcolt CR-32-es fedélzetén a köztársaságiak ellen), egy szenzációs katonai mürepülő kötelék 11 gépe. A gépek a látványos, 10 gépes kötelékbemutató után „valahogy” itt maradtak.

A Puma század a későbbiekben használt osztrák eredetű CR-32-eseket is. Az osztrákok 1936-ban 45 gépet vásároltak, amelyeket a Jagdgeschwader II-be osztottak be. Ausztriát 1938-ban Németország annektálta (Anschluss) és az osztrák gépekből átadtak Magyarországnak 36 gépet. Az osztrák gépek eredetileg ezüst festést viseltek, az Anschluss után az osztrák felségjelet egyszerűen átfestették a német jelzésekre. Később az át nem adott, megmaradt, gyakorlógépként használt gépeket RLM61/62/63/65, majd RLM70/71/65, illetve RLM71/65 német szabványfestéssel látták el. A CR-32bis változatú gépek eredetileg 4 géppuskával voltak szerelve. A két 12,7 mm-es szinkronizált géppuskán kívül az alsó szárnyak felületén, a szárnydúc belső oldala mellet 1-1 db 7,7 mm ürméretű Breda géppuska volt felszerelve. A német tulajdonban lévő gépeken a fényképek szerint már nem voltak szárnygéppuskák. A magyar gépekről készített fényképeken látszik ezeknek a

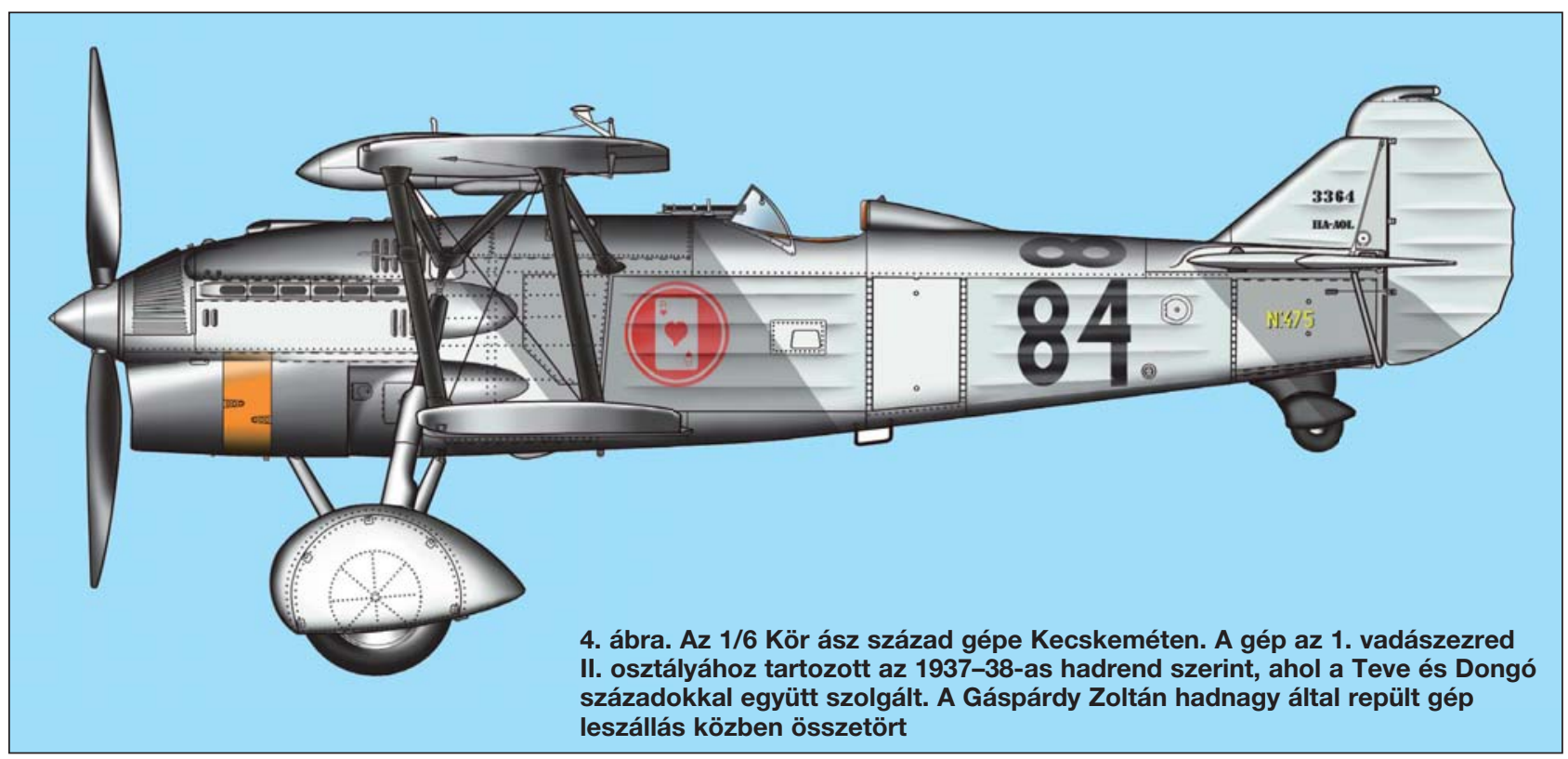




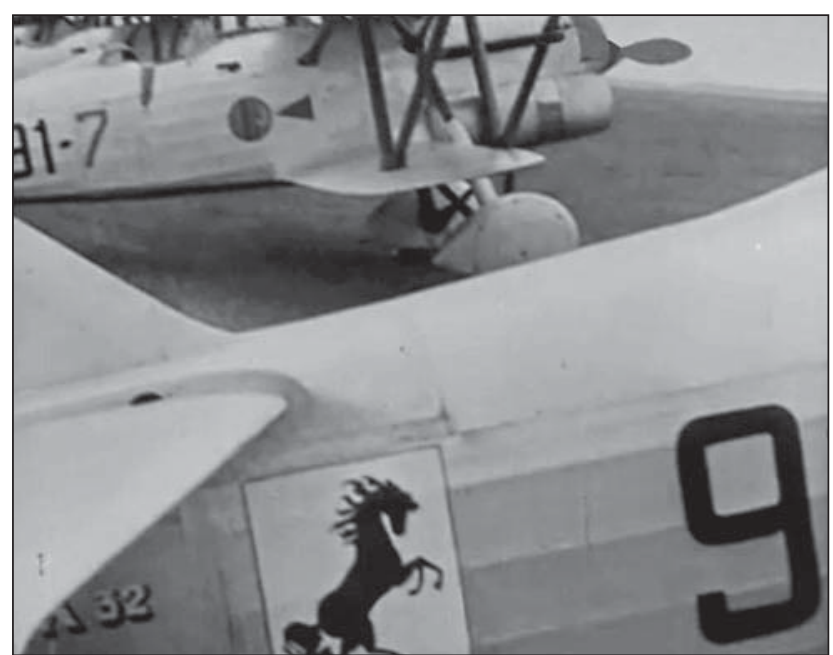

5. ábra. A felső gép Viola százados CR-32-es vadászgépe Mátyásföldön, a parancsnoki zászlócskával. A gépek az I. világháború kimagasló olasz ászának, Francesko Baracca őrnagy (36 légi győzelem) egyéni jelzését viselték, ami később a Ferrari márkajelzése is lett. A gépek a kor jellegzetes ezüstszínü festését viselik, majd ezüst átfestéssel a légierőnk gépeivé váltak helye, a fémlemezzel erősített felület és a géppuska helyét fedő rátétlemez. A magyar CR-32-es gépeken a fegyverzetet átszerelték motorhajtású 8 mm-es 26/31 mintájú Danuvia gyártású Gebauer géppuskákra, az olasz szárnygéppuska így ürmérete miatt is felesleges lett volna.

A magyar nagy tűzgyorsaságú szárnygéppuska fejlesztése ekkor még nem volt kész. Az olaszok, az 1936-1939 között folyó spanyol polgárháború tapasztalatai alapján a CR-32bis gépekről leszerelték a 7,62 mm-es szárnygéppuskákat, mivel hatástalannak találták azokat és továbbiakban a CR-32-es típust már a szárnygéppuskák nélkül, csak a nagyobb űrméretű 12,7 mm-es motorgéppuskákkal gyártották.

Az 1/5 Dongó század gépei 1937 nyarán Kecskeméten állomásoztak. A századjelvény ekkor a század gépeire nem volt felfestve, a századhoz való tartozást csak az 1/5 felirat jelezte (a $B 4$ borító fentröl az 1. ábrán látható módon). Az ezüstszínű gép légcsavarkúpjának a vége, akárcsak a Dongó század többi gépén, ebben az időszakban pirosra volt festve.

Az 1/3 Puma század 1937-ben Veszprémben állomásozott. (A Puma század 3328 LÜH számú gépe a $B 4$ borító 3. ábrán látható. A nagyméretű Puma jelvényt v. belényesi Heppes Aladár fhdgy, század elsőtiszt ötlete alapján Baráth László szkv rajzolta meg.) A század parancsnoka ebben az időszakban Nagy Mihály szds volt.

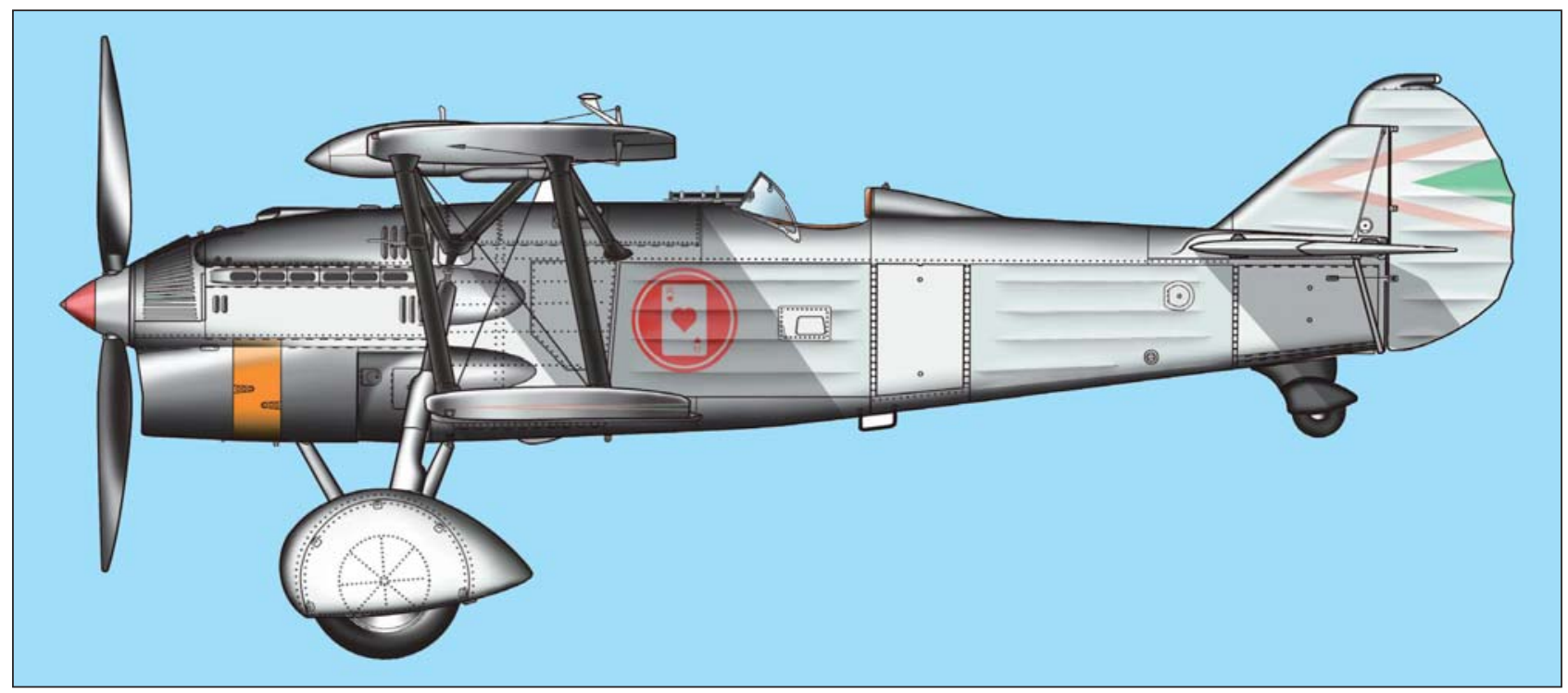

6. ábra. A Kör ász század gépe ékalakú felségjellel és gépszám nélkül. A kisantanttal Bledben megkötött egyezményt amelyben elismerték a Magyar Királyság fegyverkezési egyenjogúságát - követő napon egyetlen éjszaka alatt felfestették a felségjeleket a légierő gépeire

7. ábra. A rejtett légierő gépei az „ezüst szárnyak korszakban”. A polgári gépek nemzetiszín jelzéseivel festett ezüst színü FIAT-ok alkonyati fényben. Az $1 / 5$ század gépein, különösen az elötérben álló 73-ason jól látható, hogy az oldalszámot a törzs tetején is megjelenítették

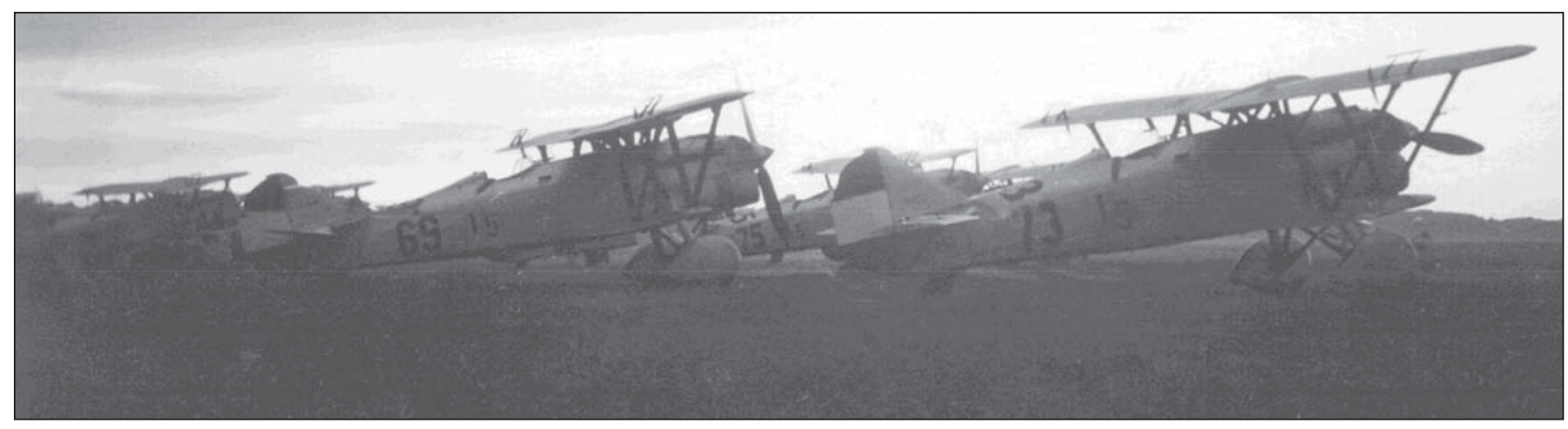




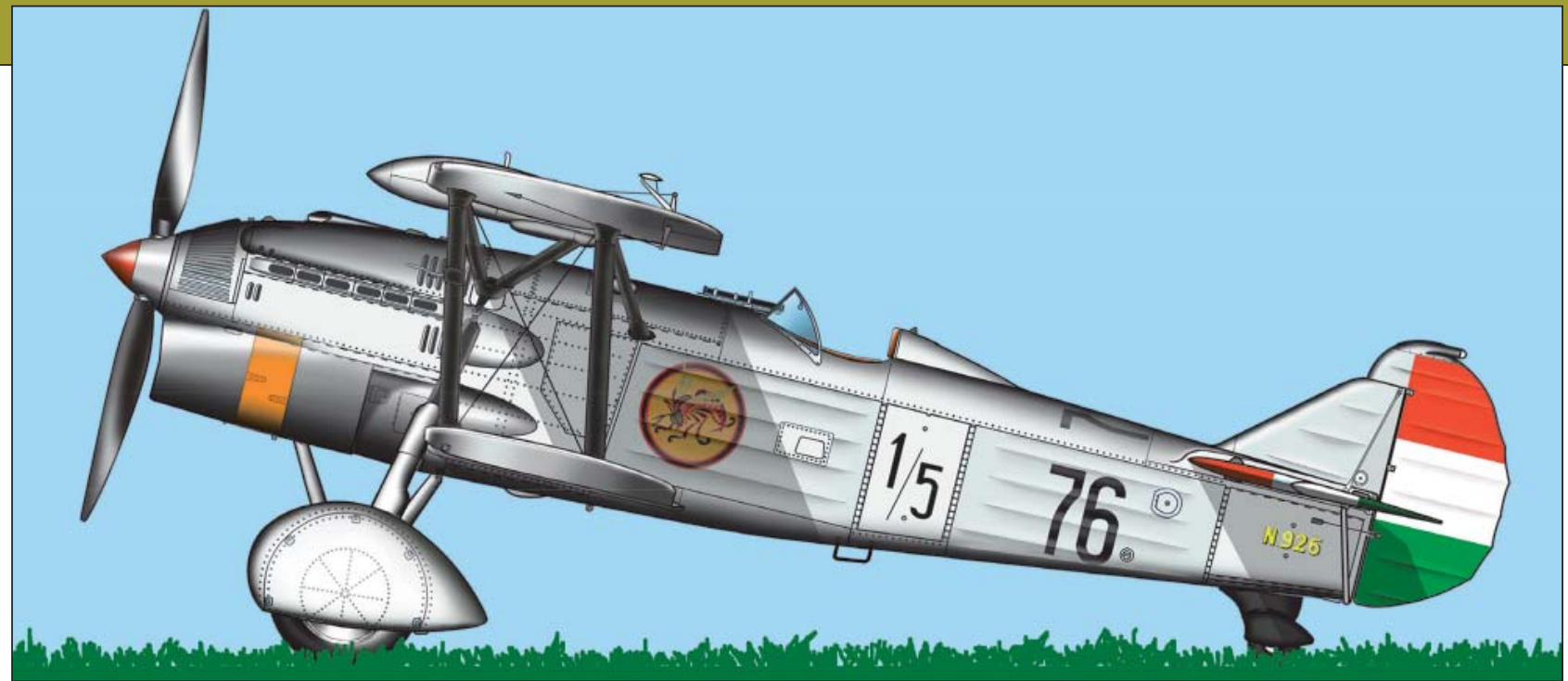

8. ábra. Az 1/5 Dongó század 76-os kötelékszámú gépe, 1937-38. A gép a 76 darabos olasz szállítás utolsó példánya. Az ábrázolt Dongó századjelvényt használták a CR-32-eseken kívül a század a Fw 56 Stösser gyakorlógépein és a Bücker Bü 131-es Jungmann futárgépein is

Az ócsai reptérre való kitelepülés idején, 1938 nyaránőszén a Kör ász század CR-32-es gépei állandó készültségben voltak a feszült csehszlovák-magyar viszony miatt. (A B4 borító fentről a 2. ábrán látható a század V.169 jelü gépe Ócsán, korai álcázó festéssel.) Ezek a gépek a feszült csehszlovák-magyar viszony miatt már részt vettek valós harci őrjáratokon. Az itt települt gépeket többször riasztották a berepülő csehszlovák gépek miatt, amelyek Budapest légterébe is bemerészkedtek. Ekkor jelent meg a gépeken a terepszín, először csak a bemutatott módon. A zöld festéket festékszóróval a törzs tetejére fújták fel, valamint a szárnyak és a vízszintes vezérsíkok felső felületére. (Egy példaként említhető a Dongó század V.159 oldalszámú FIAT gépe, amely 1938-ban a Csehszlovákia elleni fölriasztás alatt a kecskeméti, majd a mátyásföldi reptéren állomásozott. A század gépeit - a $B 4$ borító 4. ábrán látható módon - ebben az időben egyöntetű zöld terepfestéssel fedték. A gépet valószínűleg Szabó Mátyás fhdgy, századparancsnok repülte.)

A határ mentén a csehszlovák légierő vadászgépei őrjáratoztak. Egyik ilyen őrjáratból két Avia B-534-es típusú vadászgép gyalogsági fegyverektől szerzett lövésnyomokkal tért vissza. Az incidensre a válasz: a csehszlovák gépek magasabban repülve végzik őrjárataikat. Egy csendes háború zajlik, amelyben nincsenek légiharcok. Egy magyar CR-32-es géppár a kárpátaljai, föleg magyarok lakta Minaj falucskánál földi célokat lőtt, a hivatalos cseh indok szerint tévedésből, az ungvári reptér helyett. Valójában egy ott leszállt futárgépet és a körülötte összegyűlt katonai alakulatot lőtték.

1938. október 10-én Hodzsovo telepes község (a magyar etnikum fellazítására Trianon után épített és csehekkel, szlovákokkal betelepített település) határában lezuhant a 237. gyári számú Smolik Ś.328-as repülőgép, a csehszlovák légierő 10. századának pilótája Ján Kello tizedes meghalt, a megfigyelője Jaromír Sotola őrvezető megsebesült a kényszerleszállt és a sérülésektől kigyulladt gépben. A gépet az 1/2 Lúdas Matyi század 2 pilótája, a CR-32esekkel a Duna vonalán őrjáratozó Pongrácz László főhadnagy és kísérője, Major Ádám őrmester Gönyünél vette észre, amint a gép magyar légtérből visszatérve, 500 m-en hazafelé repült. A gépet megtámadták és Pongrácz a Csal-

9. ábra. A Kör ász század V.169 oldalszámú gépe Kecskeméten, 1938 augusztus-szeptember. Repülte Bejczy József hadnagy. Bejczy később a légierő egyik ásza lett: Reggiane RE.2000 Héján 2 szovjet, Bf 109-esen harcolva 1 szovjet és 3 11/2 amerikai gépet lött le

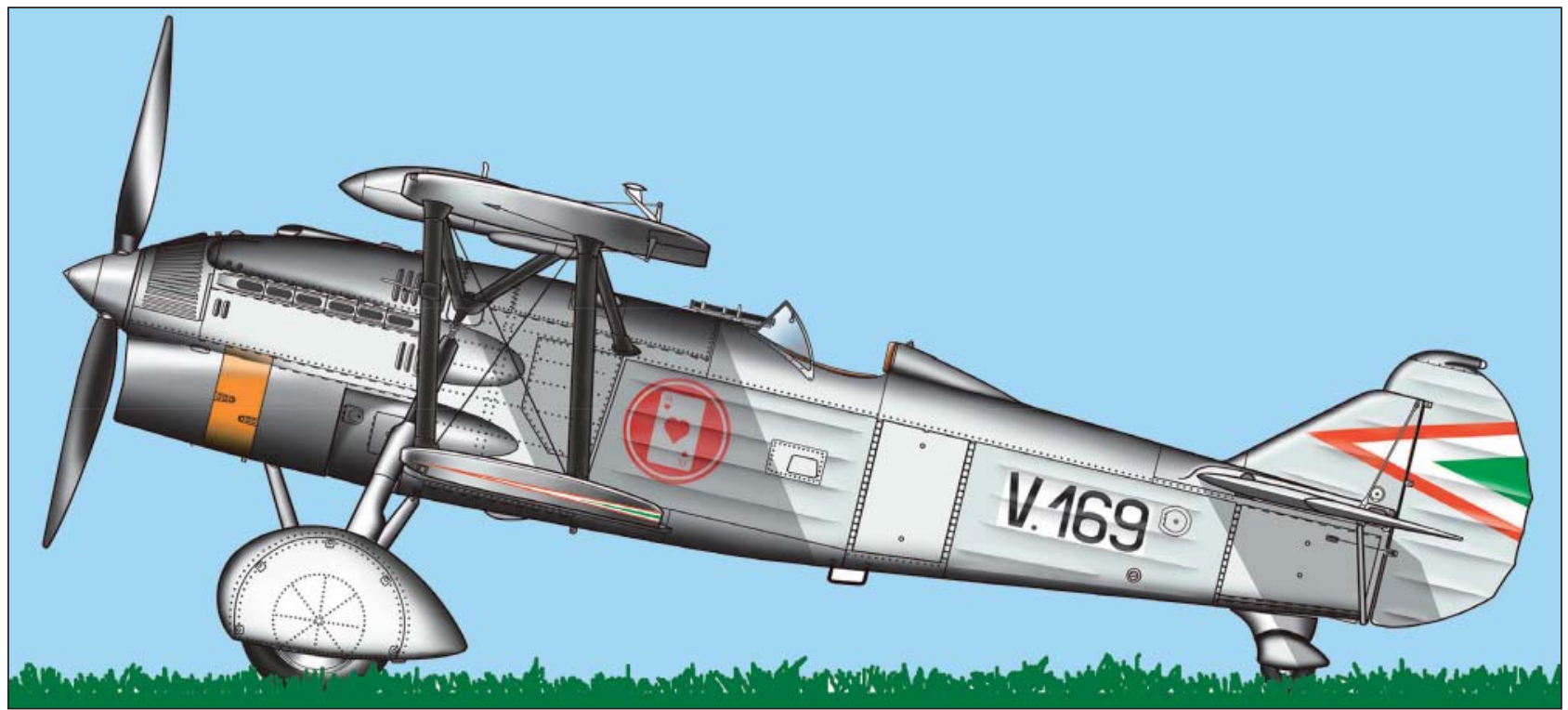




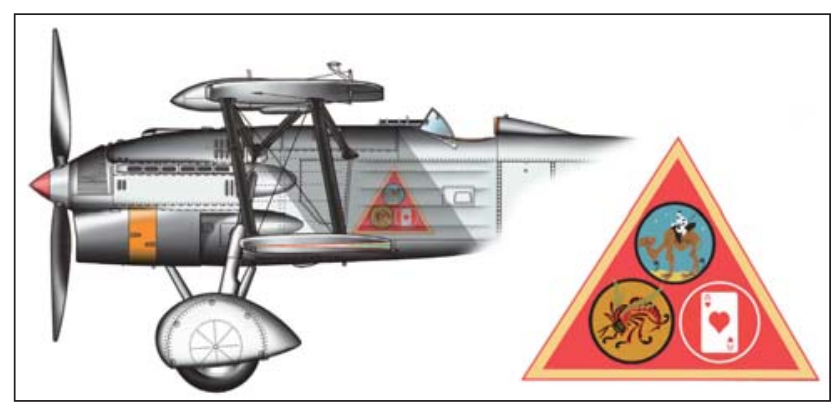

10. ábra. Az 1.2 vadászosztály osztályparancsnoki gépén, akárcsak az 1.1 vadászosztály parancsnoki gépén, olasz mintára a 1. vadászezred 2 . osztályának mindhárom századának jelvénye fel volt festve

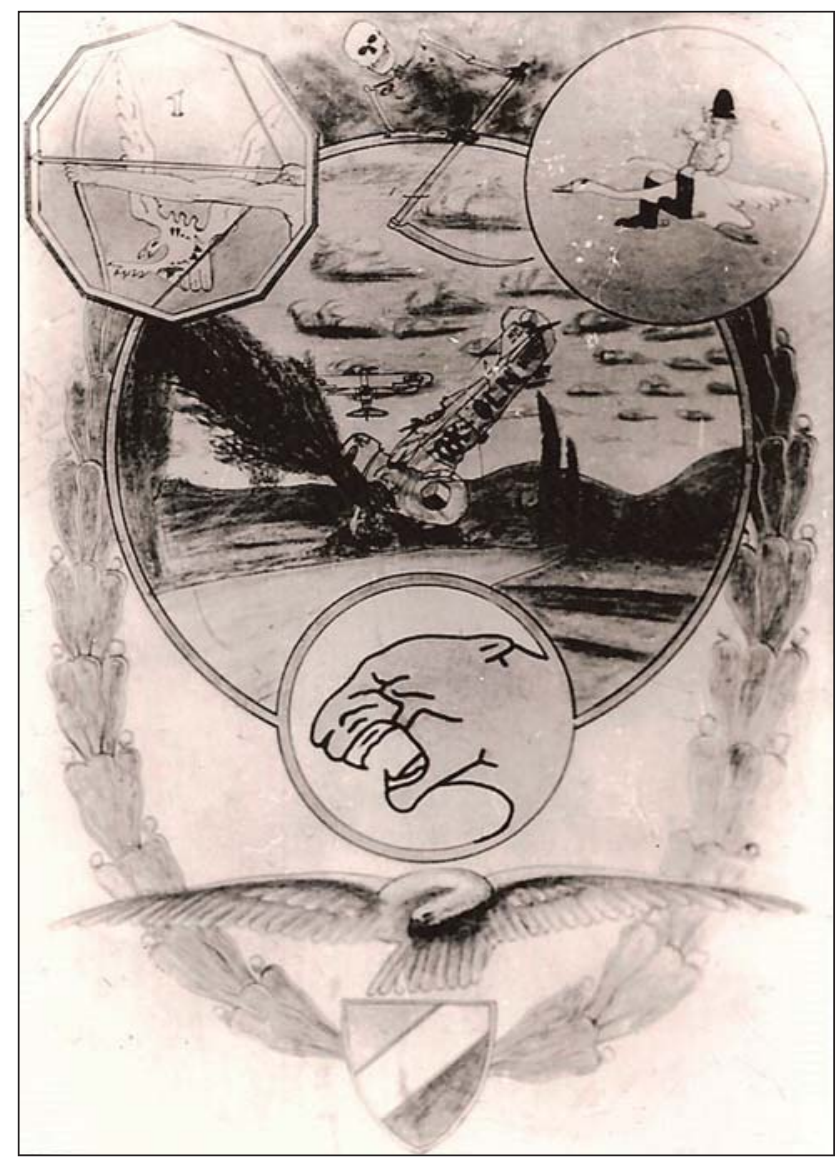

11. ábra. Az 1.1 vadászosztály századainak jelvényei korabeli képeslapon. A kép közepén egy földbe állt gép, csehszlovák felségjellel. Az 1939-es szobránci légiharcban még ilyen jelzéssel repültek a szlovák gépek

lóköz felett lelőtte. A csehek az eseményt egész másképp magyarázták. A cseh hadügyminiszter az ügy miatt előbb visszavonta, majd visszaálította azt a rendeletet, amely szerint magyar gépekre nem tüzelhetnek.

1938. október 13-án 15 h-kor a kárpátaljai Ungvárról felszállt az Ś-328-asokkal repülő 13. század egy raja. A gépek a magyar szabadcsapatok egy századát támadták Beregszásznál. A két gép közül az egyik Aszásnál, Borzsova község mellett hajtotta végre a támadást, amelynek során ledobott $6 \mathrm{db} 10 \mathrm{~kg}$-s bombát és kilőtt 25 sorozatot. Az ugyancsak Ungváron települt 31 . vadászszázad Avia B-534-esei is résztvettek az akcióban, géppuskáikkal lőtték a magyar csapatokat. Másnap kora reggel a salánki erdőnél voltak bevetésen. Ugyanaznap éjjel a határ mentén fényszórózva keresték az ellenséget. A szabadcsapatosok beszámolói szerint is egész éjjel gépek köröztek felettük és fényszóróztak.

Október és november folyamán szinte minden nap bevetésen volt a csehszlovák és a magyar légierő, egymás területei felett hajtottak végre berepüléseket. A bevetések legtöbbször rajkötelékben történtek, a gépek vizuális és fotófelderítést végeztek, földi célpontokat lőttek. Magyar részről többször megszólalt a légvédelmi tüzérség is, amelyet egyébként a trianoni szerződés nem is engedélyezett. A gépek nemcsak a határ mentén repültek végig, a legtöbb berepülés $20-30 \mathrm{~km}$ mélységben történt. Sőt, például szeptember 30-án 3 csehszlovák gép 100 km-nél mélyebben hatolt be magyar területre. Magyar jelentés szerint 2 gép rövid időre még le is szállt Szolnoktól délre. Október 5-én egy Letov Ś-328-as Smolik kf. gép repült bántatlanul Mátészalkáig, majd sikeresen visszatért repterére. Csehszlovák felderítőgépek több alkalommal is berepültek a főváros, Budapest északi légterébe és röpcédulákat dobtak le a lakosságnak.

A magyar felderítőgépek sem voltak tétlenek. A közelfelderítők két százada, az I. és a II. a határsávban repülve vizuális és fotófelderítést végzett. Náluk is tartottak a terepszínnel folyó kísérletek, a II. KF század egyik gépe átfestés (az álcázó festést módosították...) közben kigyulladt. Az I. KF század, a mátyásföldi „Holló” gépei is több bevetést végeznek a határ mentén, például október 5-én az Ipoly folyó mentén repülve, az F.302 jelű He 46E gépük csehszlovák géppuskáktól kapott lövésnyomokkal szállt le a budapesti reptéren. Szintén a Hollók egyik gépe, az F.303 jelű He 46E, fedélzetén Trón Zoltán hadnagy pilótával, október 8-án Szécsénytől északra átlépve a határt végez felderítést csehszlovák terület felett. (Trón Zoltán 1942-ben századparancsnokként ismét frontszolgálatot teljesített a Don-kanyarban.) A távolfelderítők is kivették a részüket az eseményektől. A TF 1/2 százada, a „Hétmérföldes csizma" gépei szlovák terület felett végeztek bevetéseket, ami diplomáciai tiltakozást váltott ki. De ahogy a csehszlovák gépek magyar terület feletti bevetéseit kormányuk

12. ábra. A századok között és a századokon belül verseny folyt, hogy ki tud jobb terepszínú festést készíteni. A már bemutatott V.161-es gépen is elvégezték a terepszínúre festést, ami eltért a fentebb bemutatott V.169-eshez képest. A gépen foltokban meghagyták az eredeti ezüst színt is

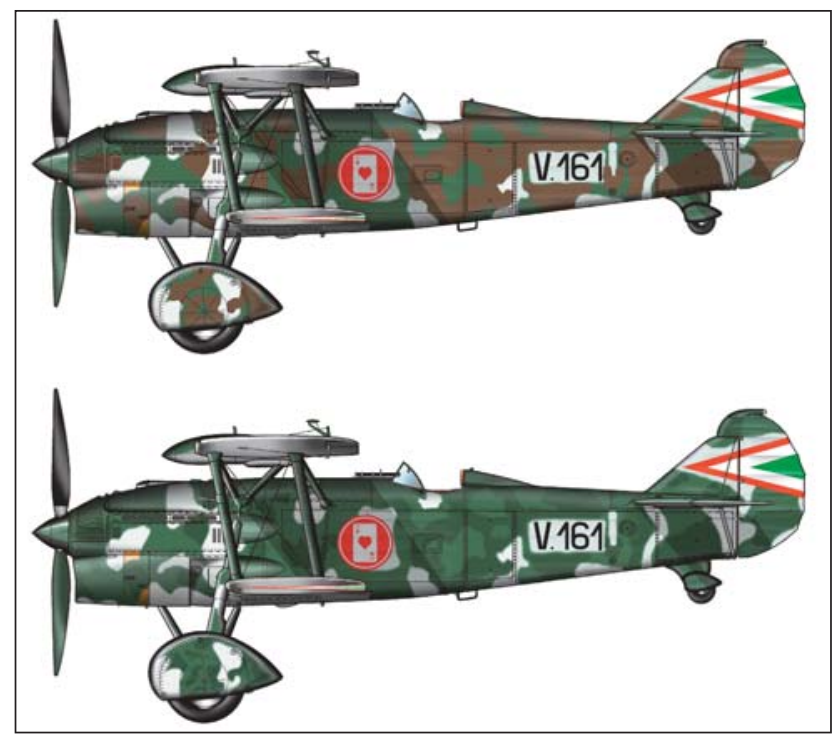




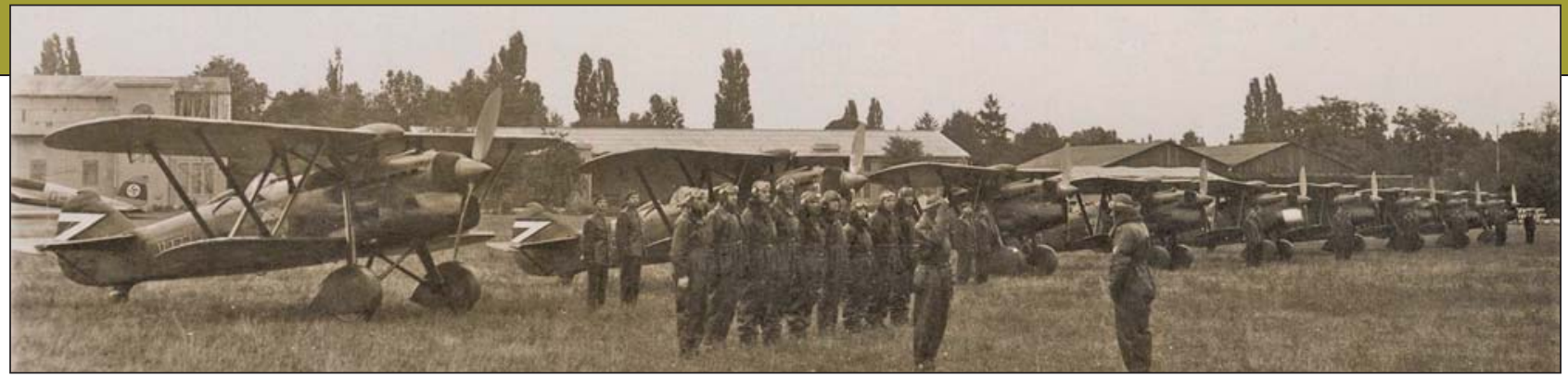

13. ábra. A Dongó század készenlétben a csehszlovák válság idején. Eligazítás a mátyásföldi reptéren. A Dongó jelvényes CR-ek egyszínü zöld terepszínben sorakoznak. A fotó érdekessége, hogy a háttérben a hangár előtt áll a német titkos egység, Rohwel ezredes kommandójának egyik polgári lajstromjeles speciális He 111 típusú felderítőgépe. Rohwel gépei több alkalommal is magyar repülőterekröl végeztek nagy hatótávolságú titkos felderítőrepüléseket. Rohwel közvetlen felettese Göring volt

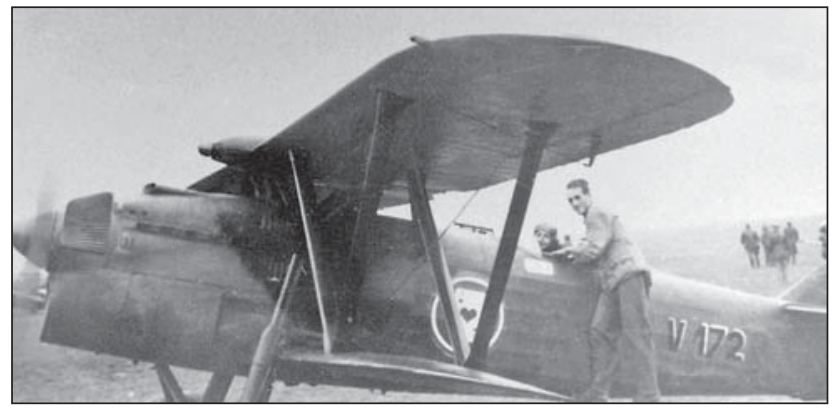

14. ábra. Az 1/5 Kör ász század gépe start elött. A járó motor légcsavarszele a szélgenerátor légcsavarját is megpörgeti. A gépen felszegecselt adattábla található a fülkekiváltás bal oldalán. A szélgenerátor az áramvonalasan kialakított, közel cseppformájú üzemanyag kiegészítő tartály elejére volt szerelve

tagadta, ugyanezt tette a magyar fél is. Szeptember 28-án Hollósi János főhadnagy pilóta F.402-es jelü He 70K gépe Mátyásföldről felszállva, a felvidéki Besztercebánya-Losonc térségében végez felderítést. (Hollósi később, 1943ban, a távolfelderítóknél a keleti fronton századparancsnokként szolgál.) Ugyanez az F.402 jelű gép október 5-én a Losonc-Rimaszombat-Kassa vonalon felderítő feladatot végez és végigfényképezi a dél-szlovákiai határmenti kiserőd rendszert.

Az események a magyar légierő számos szervezési, mozgósítási problémájára, valamint a szakképzett repülőszemélyzetek hiányára mutattak rá, amiket a későbbiekben igyekeztek orvosolni. A konfliktus során a magyar fél 294 harcigépe állt szemben a szlovák területen állomásozó 358 géppel, de nem is ez volt az aggasztó, hanem az ellenfél technikai fölénye. Például a csehszlovák vadászokban, bombázókban, könnyűbombázókban és felderítőgépekben általános volt a pörgettyűs műhorizont alkalmazása, ilyen berendezés azonban még az 1940-43 között leszállított Héjákban sem volt. Ezzel a múszerrel még a csehszlo-

15. ábra. Az 1/5 Kör ász század V.172-es oldalszámú gépe, amely 1938 nyarán Kecskeméten együtt állomásozott a Dongó és Teve századok gépeivel. Ezen a gépen a felső szárny áramvonalas, csepp alakú középső gondolájának elejére áramfejlesztő szélgenerátor van szerelve. Magában a gondolában kiegészítő üzemanyag-tartály volt

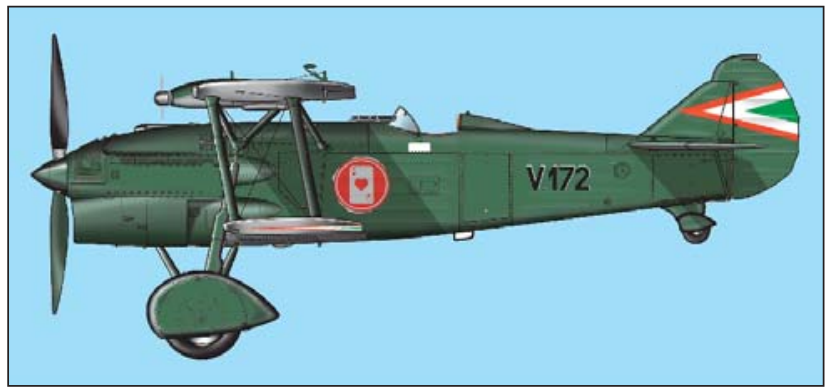

vák könnyűbombázók és felderítők is tudtak éjszakai támadásokat kivitelezni. Például a Letov Smolik típusú kf. gépe is mühorizonttal volt szerelve, ezért a gépekből ún. nehéz vadász századokat is felállítottak, éjszakai vadász feladattal. Egyébként a Letov Ś-328-as felderítő változata is $500 \mathrm{~kg}$ bombaterhet tudott szállítani, szemben a mi későbbi konstrukciójú (Fokker CV-ből fejlesztett) Sólymunk 240 kg-os teherbírásával. A konflikus során a magyar fél még öreg Fokker CV-D közelfelderítőket is bevetett... Az Aero Ab-101 kétfedelü kétszemélyes könnyübombázó, amely a mi Sólyom kategóriánk (és amelyből az elsőket csak 1939-ben szállították le) 1100 kg bombát tudott szállítani. A Nyitrán állomásozó 75. század gépeinek hasa alá akár 4 db 200 kg-s bombát is lehetett szerelni. Az Aero MB-200-as kétmotoros bombázók bombaterhelése $1400 \mathrm{~kg}$ volt, a gépek az előző évben rendszeresen gyakoroltak saját területen éjszakai támadásokat imitált magyar célok ellen. Magyar részről mindössze $9 \mathrm{db}$ Budapest 14-es könnyủbombázó állhatott csatasorba, 300-kg bombaterheléssel. A Caproni 101-es típusú 3 motoros éjszakai bombázónk (15 db) $750 \mathrm{~kg}$ bombaterhelést vihetett (1 db 500 kg-s, vagy 2 db 250 kg-s, vagy 6 db 100 kg-s), a Ju 86-os terhelése $1000 \mathrm{~kg}$ (4 db $250 \mathrm{~kg}-\mathrm{s}$, vagy $16 \mathrm{db} 50 \mathrm{~kg}-\mathrm{s}$ ). Nagy volt a pilótahiány, végre 1938. október 10-én sikerült 200 növendéket az olaszországi Grottaglieba kiküldeni pilótaképzésre, ahol (DRT, Dél-olasz Repülőtábor) 1940 májusára fejezték be kiképzésüket.

\section{FORRÁSOK}

Műszaki festékek árjegyzéke. Krayer E. és Tsa Lakk- és festékgyár, Budapest termékkatalógus Rodur színkártyával;

Repülőgépek anyagai III. kötet. Nem fémek (Műanyagok, Gumi, Textil, Ragaszok, Lakkok és festékek, Tömítőanyagok), Általános Géptervező Iroda, Bp., 1956.;

Colori e schemi mimetici delle Regia Aeronautica 19351943, Postiglione Uberto-Andrea Degl'Innocenti, 1994;

Ali d'Italia Fiat CR 32, La Bancarelle Aeronautica - Torino;

Dv. 521/1 Repülőgéplakkok kezelési és alkalmazási utasítása. I. rész: Motoros repülőgépek 1941.;

Dr. Olasz Lajos: Magyar-csehszlovák konfliktus 1938 őszén. A Repüléstörténeti Konferencia közleményei, 2010.;

Ján Petrik: Spisska tragédia 2007, Spisska Nové Ves, a Matica Slovenska támogatásával;

Avia B-534, MBI, Ing. Jirí Vrany, 1994;

Aeroarchív Avia B-534, Jiri Vrany, 1991;

Ing Jiri Vrany Letov S-328, Ilustrovaná Historie Letectvi 1991;

Img. Jan Kumbach Aero MB-200, Ilustrovaná Historie Letectvi 1987

Aero A-100, Ab101, Letectvi Kosmonautika, Monografie, 1988;

Flying Colours, W. Green-G. Swanborough, Salamander Books Ltd. 1981. 